\title{
Konrad Turek*
}

Jagiellonian University

\section{RETIREMENT AS AN EFFECT OF EMPLOYER-EMPLOYEE RELATIONS}

\begin{abstract}
Employers are the key actors in defining conditions for retirement, as well as the conditions for retaining employees; their role, however, is still not well recognised and expressed in theoretical frameworks. In order to better understand individual retirement and to design successful ageing policies we should consider the behaviour and attitudes of employers.

The article presents the organisational perspective on retirement and contributes to a theoretical consideration of the role of employers and work environments in the retirement process. It discusses the classic economic approaches, including the deferred payment model, and in referring to sociology of economy and management sciences it presents the employer's perspective in relations with older workers. The main goal of the article is to consider the retirement process as an effect of employer-employee relations.
\end{abstract}

Keywords: retirement, ageing workers, employer-employee relations, embeddedness

\section{INTRODUCTION}

In the previous century the average life expectancy grew radically but the legal age of retirement in most countries either did not change or was lowered. Specific actions aimed at increasing it have been introduced only recently. Currently, such reforms have already been carried out or are planned in 28 out of 35 OECD countries, of which 13, including Poland, are postponing the retirement age to 67 (OECD 2012). It should not come as a surprise that a system designed over 120 years ago for an entirely different social structure requires adjustment to today's conditions. However, shifting of the eligible age of retirement will not automatically relieve the federal budget. To avoid the costs of pensions being transferred to other social costs (such as unemployment benefits for older people, pre-retirement allowances or disability pensions), it is necessary to increase and extend labour market activity. Until recently, in analysing retirement processes most researchers focused on the individual level and considered incentives to employees. The role of employers was often neglected, even though success in designing an ageing policy also depends on employers (Vickerstaff, Cox and Keen 2003; Henkens and van Dalen 2013). They need to be willing and capable of providing

* Corresponding author: Konrad Turek, Jagiellonian University, Institute of Sociology, ul. Grodzka 52, 31-044 Kraków, Poland; e-mail: konrad.turek@uj.edu.pl. 
opportunities for extended employment and manage an older labour force in an effective manner. At the same time, many opinion surveys show that employers are not necessarily in favour of such changes (Conen 2013). For example in Poland in 2009 only 20\% of employers were in favour of increasing the eligible retirement age and $41 \%$ were in favour of limiting early-retirement options, yet both reforms were introduced in following years (Perek-Białas and Turek 2011). Negative attitudes and stereotypes in a work environment can constitute significant barriers to the employability of older people (Van Dalen et al. 2009).

The article contributes to a theoretical consideration of the impact of organisational environment and the role of employers in shaping later stages of workers' careers and retirement decisions. First, it presents the organisational perspective on retirement, focusing on retirement driven by company requirements. It is followed by an analysis of a classical economic approach in the form of the deferred payment model, pointing out its problems and limitations. Then, referring to sociology of economy and management sciences, the employer's perspective on the older worker is described. Finally, the article discusses the model of retirement considered as an effect of employer-employee relations.

\section{PERSPECTIVES ON THE RETIREMENT PROCESS}

The fundamental dimensions of analysis of the retirement process are the pension system and the social security system. The first provides a framework for retirement paths. The second can offer additional motivation for leaving work in the form of disability pensions or pre-retirement allowances. However, in a broader perspective, the retirement process is often considered as an effect of push and pull mechanisms, based on Beehr's model (Beehr 1986; Beehr et al. 2000). He focused on individual and environmental factors that influence individual decisions and make the retirement process voluntary or involuntary. Individual factors refer, for example, to health, financial status, personal preferences and plans. Environmental factors include among others work type, pension systems, public policy and cultural norms. All of them can push an employee out of work, as staying in it may result in negative consequences (e.g. a decrease in health or satisfaction), but they can also pull one to stay in employment (or - from another perspective - they can pull one to retirement, e.g. by a preference to have more free time or engage in voluntary activities).

Numerous studies about the retirement process have investigated a long list of such factors (Feldman 1994; Taylor and Shore 1995; Lumsdaine 1996; Shultz, Morton and Weckerle 1998; Adams 1999; MPiPS 2008). One of the most important dimensions is personal financial status. While economists focus mainly on replacement rates (the ratio of incomes and retirement pensions), psychologists pay more attention to the ratio of current and future profits and costs (Bidewell, Griffin and Hesketh 2006). Krzyżowski (2011) and Krzyżowski et al. (2014), based on qualitative research in Poland, analyse the retirement process from the perspective of an individual who adapts to cultural patterns which determine the shape of social roles in older age. Among push and pull factors they specify health, family relations, care obligations, loss of job, possibilities of finding employment, relations with co-workers, willingness to take a rest, and a need for stability and security. Other research also considers relations with a partner (linked retirement decisions, $c f$. Blau 1998). Some research also shows that older workers 
are often forced into retirement - either by cultural norms or by employers, who do not see any place for them or prefer to employ a retired person (which is cheaper and provides more flexibility in dismissal) (MPiPS 2008: 122-125). Many of the push and pull factors affecting individual retirement decisions are presented in Figure 1.

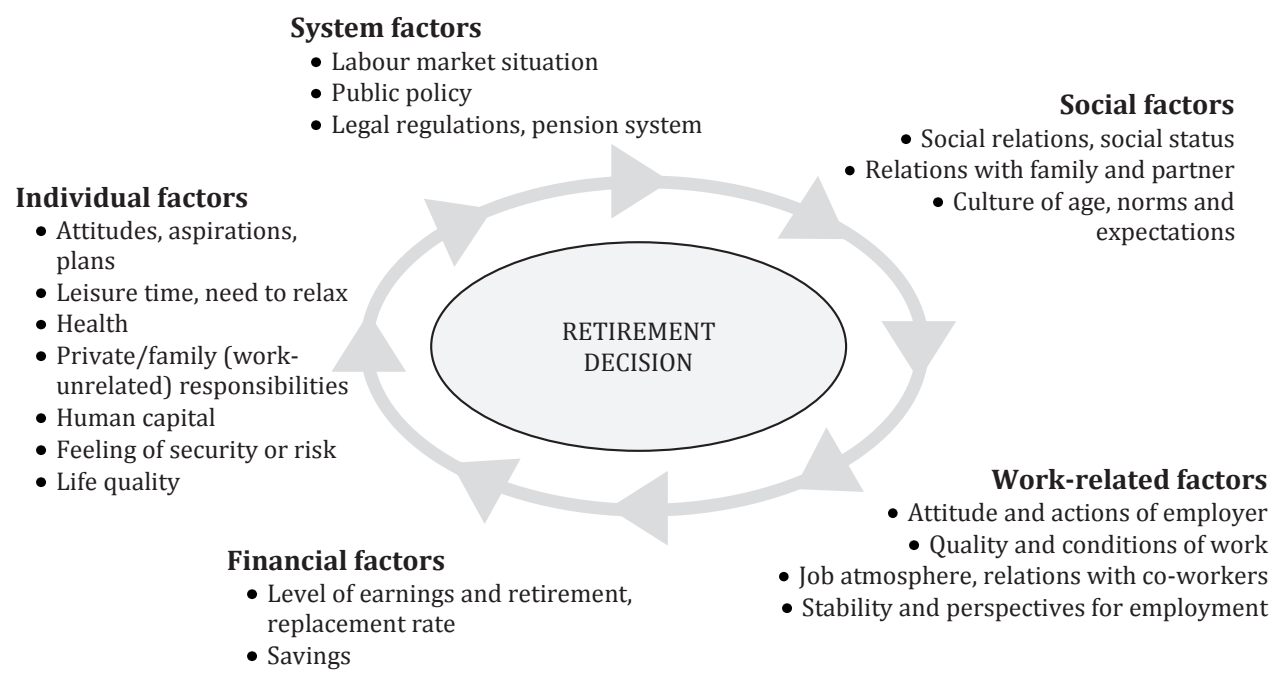

Figure 1. Some determinants in the retirement decision

Source: own elaboration

Domination of push or pull factors in the retirement process can have consequences for later life satisfaction, depending on whether the post-retirement reality meets individual expectations. For instance, earlier retirees whose decision to leave employment was directed mainly by factors pulling them to the retirement have felt lower levels of depression and sadness than their colleagues who stayed in work, whereas early retirement driven by push factors resulted in decrease in satisfaction and difficulties in adjustment to the new situation (Shultz et al. 1998; Greller and Simpson 1999).

A useful framework for analysing the retirement process provides specification of three structural levels (among which push/pull factors can also be considered):

- individual (micro-level) - focuses on health condition, skills, financial status, savings, leisure, work attitudes, work-life balance, caring responsibilities, work requirements, job satisfaction, retirement of a spouse, life-course phases etc.

- system (macro-level) - refers to public policy, pension system, replacement rates, labour market situation, culture, age norms etc.

- organisation/work environment (mezo-level) - covers opinions, attitudes and actions of employers, organisation-level policy, work conditions, work atmosphere, type of work etc. 
The most popular is the individual level of analysis, where the retirement is viewed mainly as a voluntary and employee-driven transition, as a matter of individual choice and preferences (Henkens and van Dalen 2013). A wide range of literature also focuses on the system perspective, especially on the influence of pension system regulations on individual preferences (Hanushek, Maritato 1996; Hinrichs 2009; García-Pérez, Jiménez-Martín and Sánchez-Martín 2013; Holzmann 2013). Very often both these levels are combined in the analysis.

The last perspective, organisational, is least developed. Henkens and van Dalen (2013) emphasise that employers are the key actors in defining conditions for retirement, as well as the conditions for continuing work, although their role is still not well recognised or expressed in theoretical framework. Vickerstaff, Cox and Keen (2003), in analysing case studies of British companies, found that earlier retirement was mainly driven by employer requirements and the situation of the company, not by public policy. Thus, they conclude that the main force of any significant change in retirement behaviour is the employer. It may seem that such a conclusion goes too far, as analysis or retirement requires including the individual and the system as well. However, undoubtedly the attitudes and behaviours of employers influence retirement patterns.

\section{RETIREMENT DRIVEN BY COMPANY REQUIREMENTS: DEFERRED PAYMENT MODEL}

Consideration of retirement as a process driven by company requirements results from research about relationships between the worker's productivity, income and age. It first attracted the attention of economists who have been systematically investigating this relationship since the 1950s (cf. Clark, Kreps and Spengler 1978), giving an impulse for development of the economy of earnings and human capital theory.

The neo-classical economy assumed that employers are remunerated according to their marginal productivity (Greller and Simpson 1999). For a long time a prevailing assumption said that productivity first increases, then decreases in older age, adopting an inverse-U shape (cf. Skirbekk 2004). At the same time cross-sectional and longitudinal research of income profiles across age groups (mainly in the US) showed that earnings generally increase until the age of 40-55 years and then stay on the same level or slightly decrease at pre-retirement age (Becker 1964; Mincer 1974; cf. Neumark 2006). Differences were found only in the slope's steepness (the pace of changes), the peak age, and the length of stabilisation period (and of course the nominal level of incomes), which depended on the country, work group, education, historical period, etc. One of the most prominent neo-classical approaches, human capital theory (Mincer 1958; Becker 1964; Ben-Porath 1967), assumed that the increase in productivity and in income results from the continuous increase of human capital of the individual, although in older age they can both decrease.

Combination of the two age profiles (productivity and income) indicates the possibility of a wage-productivity gap - a situation when income does not match marginal productivity (Lazear 1979) (Fig. 2). Since the 1970s it has been a popular subject of research. According to the human capital theory any gap results from the costs of investment in human capital in 
younger age, but from the perspective of the entire working life the average income equals productivity. However, many theoretical models from the 1970s and 1980s questioned the basic assumptions of human capital theory ( $c f$. Polachek and Siebert 1993). The neo-institutional approach in economics emphasised that productivity and incomes are not ideally correlated due to moderating mechanisms embedded in institutional and structural relations (Greller and Simpson 1999). Among them were seniority rules, according to which an increase in earnings and promotion of an employer resulted in the first place from tenure, with no or little relation to productivity (Mincer 1974; Carmichael 1983; Hutchens 1989; Barth 1997). Such implicite or explicite rules could be an effect of trade unions' influence (e.g. Booth and Frank 1996), legal regulations (e.g. in the public sector or a part of pre-retirement labour protection employment), tradition and culture (e.g. in Japan), or it can play a motivational role (Ilmakunnas et al. 2004).

Most importantly, however, the wage-productivity gap meant a potential loss for employers. Regardless of whether it really appears or what size it reaches, even an assumption that it could emerge was an important barrier for the employability of older workers. It also had consequences for the length of the work life and for retirement, what was emphasised at best by the concept of deferred payment that stated the basis of analysing retirement as a process driven by the company's requirements (Fig. 2).

The classic deferred payment model was developed by Lazear (1979), Lazear and Moore (1984) and Medoff and Abraham (1980; 1981). The famous "Lazear's contracts" were long-term, unwritten contracts between employer and employee. According to them, at the beginning of one's career earnings are lower than the marginal productivity indicates, while in the last stage of employment the relation inverses. This mechanism of deferred payment should motivate employees to work and stay in the company. The model indicated existence of a final point in time when the employee retires in order to complete the period of overpayment. Such contracts should be beneficial for both sides. The deferred payment system discourages an employee from committing fraud or abuse and performing low quality work, as only those profitable and reliable will stay in the company and receive the delayed reward (cf. Hutchens 1987).

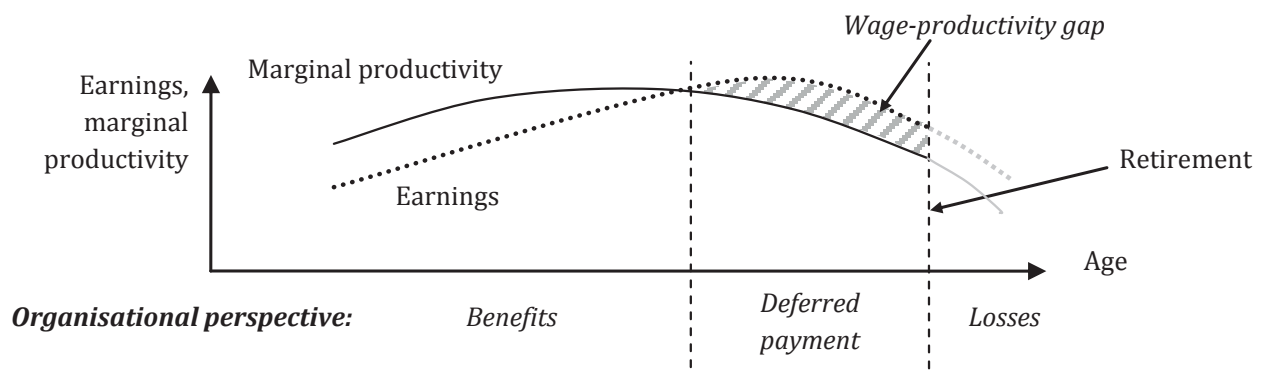

Figure 2. Deferred payment model

Source: own elaboration 
Medoff and Abraham (1980; 1981) used the mechanism of implicite contracts between the employer and employee for explaining data from US companies, according to which the increase of earnings with tenure weakly correlated with productivity ratings done by supervisors. Later on much other research also involved this model for interpreting the results (e.g. Harris and Holmstrom 1982; Hutchens 1987, 1989; Barth 1997; Dustmann and Meghir 2005). For instance, Kotlikoff and Gokhale (1992), based on 300,000 employment records from a 14-year period, interpret the observed wage-productivity gap as consistent with Lazear's theory and inconsistent with Becker-Mincer's human capital theory.

\section{PROBLEMS OF DEFERRED PAYMENT MODEL: PRODUCTIVITY, INCOME AND TIME}

\section{PRODUCTIVITY}

Despite the long tradition of theoretical and empirical elaborations, the basic assumption of neo-classical economics about the trajectory of productivity and earnings, as shown in Figure 2, does not necessarily has to be met. First of all, research on the relationship between age and productivity, whether measured at the individual level or at the organizational level, does not allow one to draw firm conclusions about a drop of productivity in older age. Metaanalysis and extensive literature reviews indicate that although the age effect is sometimes observed it is not always significant; in many cases it does not occur at all, whereas some research shows an increase in performance in older groups (McEvoy and Cascio 1989; Sturman 2003; Daveri and Maliranta 2007; Hellerstein, Neumark 2007; Ng, Feldman 2008). Age-productivity relationships cannot be easily generalised. Productivity does not depend on chronological age, but on a set of individual characteristics of the worker and conditions under which she or he works. Thus age alone does not directly influence productivity. The relation depends on (a) individual factors, (b) type of work, (c) HR management and company policy (cf. Turek and Perek-Białas 2013).

Social psychology and management sciences usually talk about workers' job performance (leaving productivity for economists, although sometimes these terms are used interchangeably). In the classic approach of these sciences, job performance was regarded as a function of capacity (related to age), willingness, and opportunity to perform (Blumberg and Pringle 1982). Skirbekk (2004) adds an important element - productive potential - which is the result of individual determinants of productivity (Fig. 3).

This issue was considered even more broadly in the concept of "work ability", developed in the early 1990s by the Finnish Institute of Occupational Health (Ilmarinen and Tuomi 1992; Ilmarinen 2001). Work ability is the result of the functioning of the human resources in a specific job (Fig. 4). It can be presented in a form of hierarchical structure. The first level is composed of functional abilities (physical, mental, and social). The second level refers to competence, skills and knowledge. The third concerns values, attitudes, motivation and satisfaction. Finally, the fourth level is the work environment: work demands, community and management. Family and friendship relationships are also meaningful, as are the social, 
political, legal, economic, and infrastructural environment. Ilmarinen and his colleagues, however, particularly emphasize the importance of the work environment. Until recently, the most common response to the growing demands of a job was to raise the level of human resources (e.g. by training). However, according to their concept, high work ability requires also improving the quality of working conditions and management.

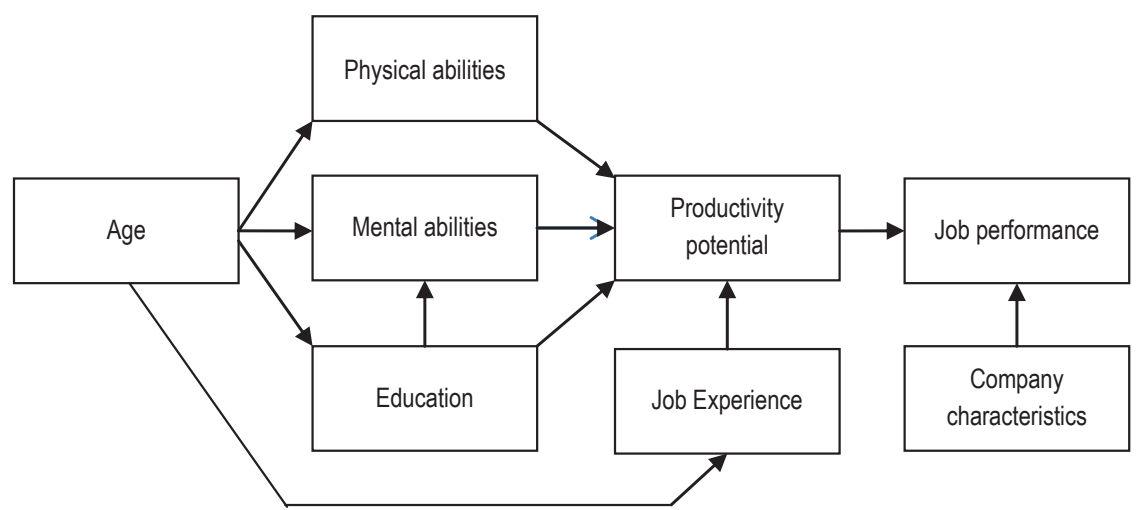

Figure 3. Factors influencing job performance

Source: Skirbekk 2004: 152

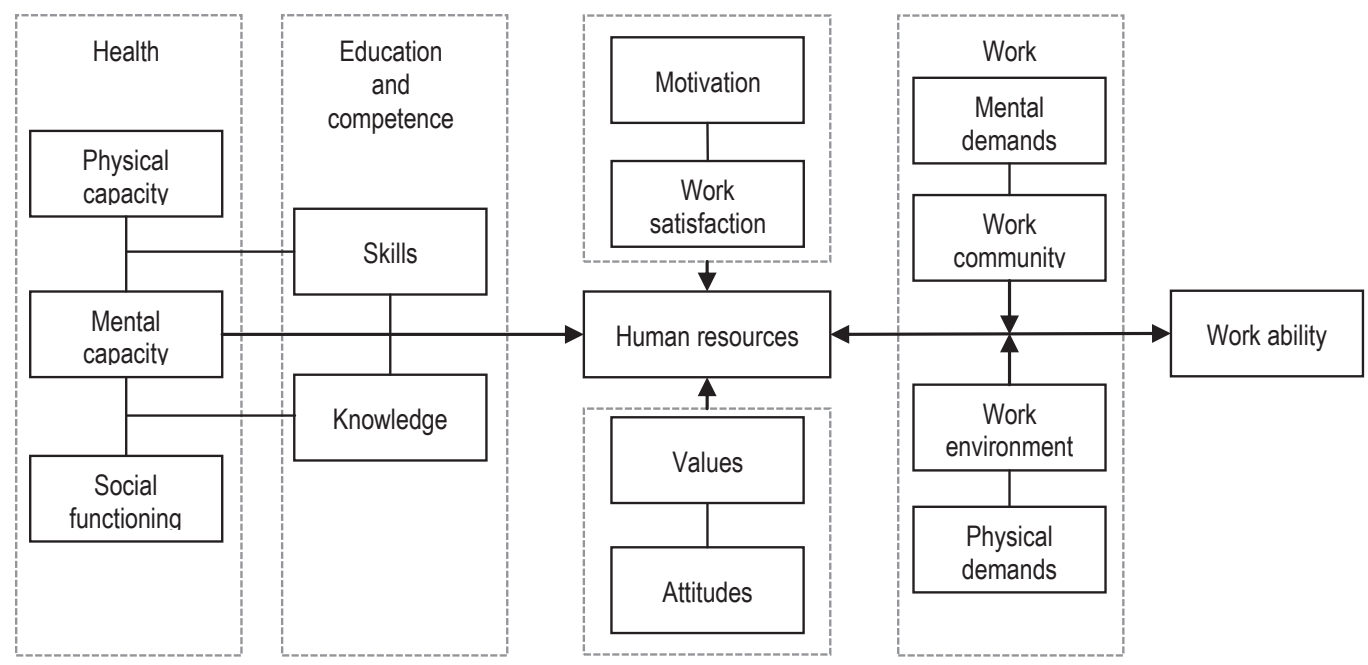

Figure 4. Work ability model

Source: Ilmarinen 2001: 549 


\section{COSTS AND TIME}

The second problem of the deferred payment model refers to the understanding of costs and time. First of all, earnings are not the only cost generated by a worker. Human resources literature specifies many other types, including costs of recruitment and employment, training and development, placement, management, system costs of work (taxes), absenteeism, and alternative costs (e.g. cost of lost productivity during training) (Flamholtz 1999; Ng, Feldman 2008). It also specifies direct and indirect costs, and it distinguishes between costs and investments. Such a broader perspective can change the curve and its relation with age, especially if we consider investments, as then it is necessary to include the period of return.

As well, the temporal character of the relation between employer and employee was often simplified when considering the consequences of the wage-productivity gap. Although Lazear's model of deferred payment considered the career-time relation of productivity and earnings, it neglected the relationship between the particular employer and the particular employee and the fact that workers change jobs. Employers do not only assess the current marginal productivity or current costs, but consider a longer period. Therefore, what has to be included among the others are previous performance, expectations about future performance and costs, and expected period of work in the company.

\section{EMPLOYER'S PERSPECTIVE ON THE (OLDER) WORKER}

\section{LIMITATIONS OF EMPLOYER'S DECISIONS: EMBEDDEDNESS AND MENTAL MODELS}

Trying to specify the role of employer for retirement decisions of workers we should sketch out the employer's perspective. First, we have to consider the limitations of the employer's knowledge, skills and possibilities.

Harris and Holmstrom (1982) offered an alternative to Lazear's model. Rather than focusing on retirement, they considered the functioning of actors in a situation of incomplete information. The initial earnings are usually relatively low because employers do not know how young, newly hired employees will perform in the job. On the other hand, at the beginning of a career the employee does not know his or her value either. Hence, both sides have to learn to observe the effects of work. Importantly, Harris and Holmstrom emphasised that employers specify the workers' value based on a subjective and imprecise assessment of productivity. Long-term contracts which average the life-time earning play a role of protection: for the employer, against lack of information about productivity, and for the employee, against short-term decreases in productivity ratings resulting in loss of income. Older workers have enough time to learn and prove their value and to negotiate higher earnings, at the same time lowering insurance costs (due to the decrease in remaining work time). As well, Bishop (1987) proposed replacing strong assumptions of neo-classical human capital approach by asserting that wages actually depend on the marginal product expected by the employers, given the employer's incomplete information. 
The limitations of actors' knowledge and decision-making processes has been analysed by sociology and psychology. One of the key concepts in the sociology of the economy referring to economic behaviours is embeddedness (Granovetter 1985). It concerns the impact of certain individual and external factors on economic activities of the individual, as opposed to the under-socialised vision of the individual in the most basic view of classical and neoclassical economics, which assumes a free market of perfectly informed sellers and buyers, who act fully rationally, but do not maintain any relations other than economic.

Zukin and DiMaggio (1990) distinguished four types of embeddedness: structural, cognitive, cultural, and political. The central element of structural embeddedness is the recognition of economic relations as interpersonal relations oriented and limited by the network of relationships between actors and patterns of social relations. An example of the impact of structural embeddedness is reduction of negative age stereotypes of managers in highly individualized relations with familiar older people, compared to relationships with new or unknown employees (Perry and Finkelstein 1999; Posthuma and Campion 2007).

The cognitive dimension of embeddedness refers to the mental limitations of economic reasoning which cause individuals and organizations to not follow the neoclassical model of rationality. This leads to the adoption of the concept of bounded rationality of actions. One of the main limitations is the lack of complete knowledge about the current situation and the uncertainty of the consequences of actions. Obtaining information, if even possible, is often associated with certain costs. The process of inference is also limited by the cognitive capabilities of the individual, the level of information-processing skills and ability to make decisions. In the context of the situation of older workers, one of the main barriers to job retention may be the lack of knowledge and skills of employers in the field of age management.

Cultural embeddedness concerns the role of collectively shared interpretations in shaping strategies and economic goals. Culture, in the form of beliefs, ideologies, common opinions, and sets of norms and regulations, in fact imposes certain restrictions on the freedom of economic activities, influences the selection of goals and patterns of behaviour, and imposes interpretations. For example, cultural norms are important in determining an "adequate" retirement age (in this context we can speak about the culture of age, $c f$. Guillemard, Rein 1993). This type of embeddedness also clearly reveals differences in the content of age stereotypes among employers from different countries (e.g. Harper et al. 2006).

Finally, political embeddedness concerns the asymmetry of power relations between the actors. This asymmetry may result from legal frameworks, unequal access to resources, and the degree of social legitimacy. The impact of legal norms and public institutions on the functioning of companies is an obvious example of this kind of embeddedness. This perspective refers to one of the most important paradigms in research on ageing today, the political economy of aging (Phillipson 2006). It focuses, among others, on the ways a political system shapes the opportunity to engage older people in economic activity, and also analyses the process of dependence of older people on social policy, health systems, and social services. 
Social psychology introduced the concept of mental models to describe the rules of reasoning for explaining behaviours of individuals and entire communities (Denzau and North 1994; Mathieu et al. 2000). Mental models are organized knowledge structures that allow individuals to describe, explain and predict events. In particular, they allow one to understand and interact with the environment, predict and explain the behaviour of others, recognize the relationships between the elements of the environment, and build expectations for the course of events. They also affect inference and decision-making. They are often shared by individuals operating in the same environment (e.g. work), which allows them to collaborate effectively, and efficiently respond to challenges and difficulties.

The concepts of embeddedness and shared mental models indicate that the key elements in the framework for interpreting the relationship between an employer and an older employee are internal and external limitations. Economic activities do not happen in a social vacuum. Structural, institutional, cultural, and political influences as well as psychological processes are important for the development of the situation of older workers.

\section{EMPLOYEE'S VALUE TO THE ORGANIZATION}

Human capital theory treats the worker and his or her work as an asset that contributes to the benefits and costs of the company. Estimation of the value of any type of capital (e.g. financial or technological) requires one to consider what will happen with it in the future (e.g. what profits will it bring). In cases of non-human, exchangeable capital an indication is given by the market price. However, human capital is not a subject of trade, thus the uncertainty of its value is higher (Lev and Schwartz 1971). Generally, estimation of a worker's value requires one to asses (within the perspective of time) his or her productivity, promotability, transferability and retainability (Fitz-enz 2009: 134). In economics and management sciences the individual's value to an organization is often defined as the present value of the future services the individual is expected to provide for the period of time the individual is expected to remain in the organization (Flamholtz 1999: 160).

The Human Capital Accounting (HCA) approach transformed this kind of definition into a form of analytical models. It aimed at estimations of employee's value in real numbers the so-called discounted present value of the worker, based on functions of such factors like expected future work performance, future costs, age, and time of retirement. For instance, in the classic model Lev and Schwartz (1971) used a simple equation for the human capital value of a person that included annual earnings (estimated with help of statistical data for sector) and expected age of retirement. Flamholtz (1972a; 1974/1999) proposed a more complex, both in mathematical and theoretical terms, model of an individual's expected realizable value (Fig. 5). The value was based, inter alia, on probability of leaving the company before retirement age, satisfaction, motivation and fit to the position. Flamholtz also emphasised that the individual's skills and knowledge are important to the organisation only if they are used in a productive way (Flamholtz 1972b), therefore he included in the model motivation for their use (i.e. activation level). 


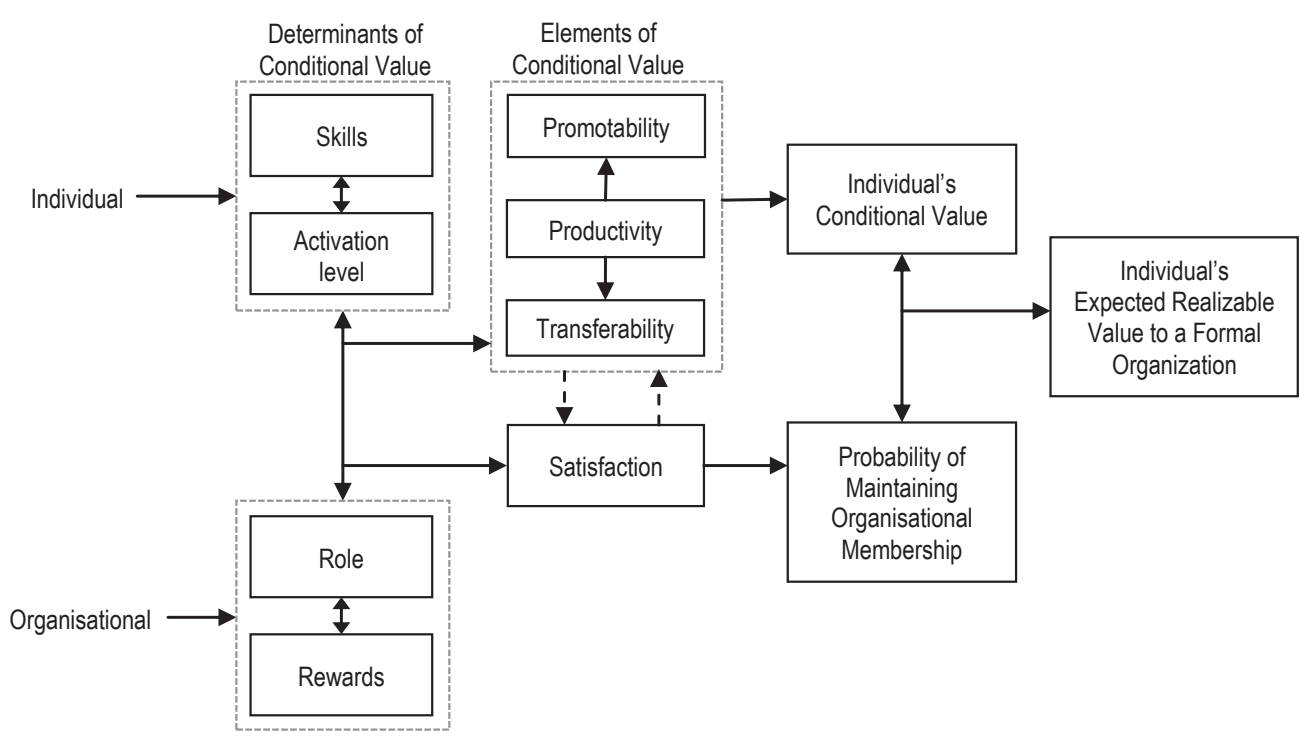

Figure 5. Model of employee's value to an organisation by Flamholtz

Source: Flamholtz 1972b: 668

Morse (1973) suggested focusing on human resources of the whole organisation rather than on the individual human capital. It required including in the model an additional part responsible for the individual capacity to work as a team.

After a period of great popularity in the academic world of the United States in the 1970s, the interest in HCA decreased. A rebirth was observed in the late 1980s and 1990s with the development of the knowledge-based economy and the increasing role attributed to the human capital of workers: employers were looking for support in assessing their situation and in management (Flamholtz, Bullen and Hua 2002).

However, the value of HCA was often criticized (Andrade and Sotomayor 2011). Firstly, practical application of complex models in a particular organization was often difficult, timeconsuming, costly, or even impossible. Furthermore, most of these approaches (except the Morse model) focused on individual value, while in the modern economy the view that work is a team process and a worker should be assessed as a part of it dominates. Yet, the fundamental problem with HCA was in the assumptions required for the particular parts of equations. All of the models were based on the values of future behaviours and situations expected by an employer (or HR specialist). The models at the theoretical level were more complex, as more assumptions were needed for mathematical predictions. Each subsequent prediction was exposed to additional error. Employers, like all people, have limited knowledge of place and time: their actions are often based on past experience, intuition, simplifying assumptions or 
stereotypes. Phelps (1972) suggested that employers seek to maximize the expected profit and build expectations about employees' future behaviour, performance and costs and according to these make their decisions. These expectations can be based on prevailing sociological beliefs (stereotypes) or on previous statistical experience, i.e. knowledge about how certain categories of workers normally perform at work, how they develop and what their career paths are. However, the economy is never fully predictable. Even when based on previous experience the predictions may be inaccurate. Arrow (1998) noticed that, first, in the real labour market employers have very limited experience, and second, it is often impossible to measure an individual's performance, or such measurements are inaccurate. Therefore, even if the employers are trying to make decisions based on knowledge, it is impossible not to use some kind of preconceptualization, generalization or prejudice. This can of course result in discrimination (Conen 2013). What is more, employers are not able to fully predict the consequences of their actions or reactions of employees to the change of situation in which they operate.

Despite the critiques, Human Accounting Models were successfully used in the practice of firms, but only if used wisely (Gröjer and Johanson 1998). In default of other sources of information, every clue, however imprecise, is valuable when it brings profits. This confirms the rather uncontroversial conclusion that employers seek out different methods to evaluate employees and anticipate their development, and the costs and benefits they can bring for the company. From the employer's point of view such strategy is rational: it reduces uncertainty, limits the financial and time costs of collecting data about employees, and facilitates and speeds up decision-making in the company.

\section{RETIREMENT AS AN EFFECT OF EMPLOYER-EMPLOYEE RELATIONS}

Despite the inevitable margin of unpredictability, the relationship between employer and employee in a particular social, political and economic environment can be grasped in a theoretical model. The model presented in Figure 6 summarizes the process of retirement considered as the result of the relationship between worker and employer in a specific context. The employer, with his or her knowledge, experience, attitudes, opinions, plans and expectations (e.g. about future developments in the market and the behaviour of other actors), formulates expectations about the employee. On the one hand, they are based on productive potential, age (and other characteristics that could potentially be relevant to the employer, such as gender, appearance, ethnicity or sexual orientation) and employment history (all the knowledge that the employer may have about a particular employee). On the other hand, expectations are influenced by the work environment: characteristics of the sector and the specific company such as organisation-level policy, earnings systems, and work conditions.

Expectations about the employee are composed of three fundamental elements. The first one is the expected cost (defined by the employer, they can cover different categories of costs, including indirect and alternative). The second element is the expected performance and additional value, which is performance understood in a broad perspective, as in social 
psychology (Ng, Feldman 2008). It includes not only the core work tasks, but also involvement in the life of the organization, communication with co-workers, helping others, one's impact on the team, adhering to the rules and standards, accepting the company values, as well as discipline and loyalty. The third element is the expected remaining time of work, which can also be defined as the probability of leaving work due to job change, retirement or other events. The employer in making decisions includes the potential period in which the employee will bring profits to the company. From this point of view, employees who - in the mind of the employer - will not leave the company in the near future have a higher value.

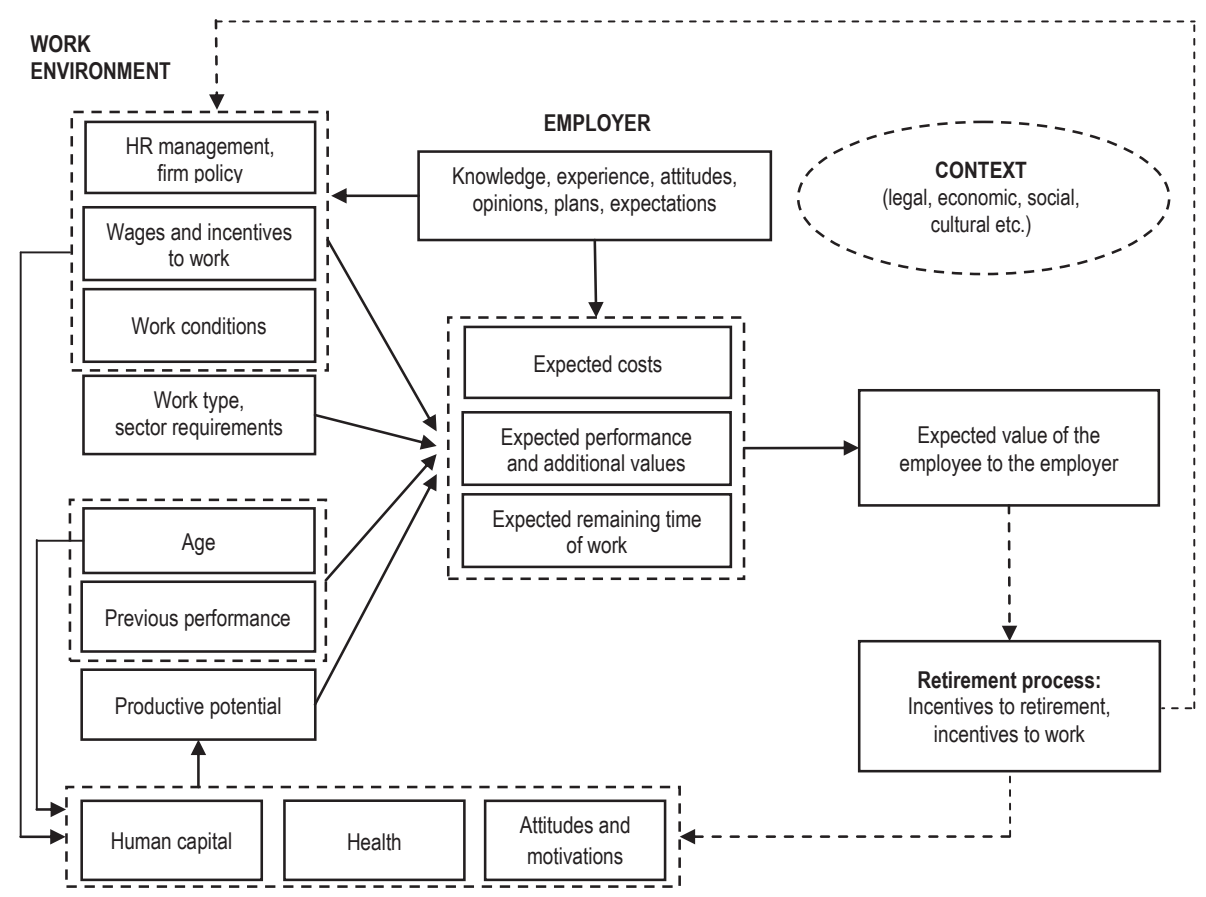

EMPLOYEE

Figure 6. Retirement as an effect of employer-employee relations

Source: own elaboration.

Based on these three components, the employer constructs something management sciences (e.g. Flamholtz 1999) call the expected value of the employee to the employer, i.e. the present value of expected future services the employee will provide in the period in which he or she is expected to work for the organization. Expectation of declining performance of an older worker and rising or stable wages can lead to the expectation of a wage-productivity 
gap, which means losses for the company. This can result in actions pushing the older worker into retirement. Employers who prefer younger or middle-aged workers will not be as willing to invest in the development of employees approaching retirement age, nor in age management, career planning or training programs. The reduction of the number of older workers can be seen as an effective tool in solving temporary financial problems and lowering labour costs (Taylor and Walker 1998). In the case of older workers an unfavourable approach of employers may negatively affect their well-being, decrease motivation to work, and consequently decrease performance, and as a final step it can result in the decision to retire as soon as possible. This creates a vicious cycle, negatively affecting both sides of the employment contract. It may also adversely affect the prospects of older job seekers. A different character of this relationship (based on favourable approach to ageing staff) can bring the opposite effect. Therefore, attitudes and actions of employers are a central element of the analysis of retirement process at the organizational level.

\section{CONCLUSIONS}

The article proposes considering the retirement process as an effect of employer-employee relations. It is of a theoretical character but evidence on the significance of employer-employee relations for retirement decisions is found in the literature. Research in Poland has shown that employers' opinions about the lower productivity of older workers correlated with organizational policies aimed at pushing older workers to retirement, while positive opinions correlated with the policy of active age management (Perek-Białas and Turek 2012; Turek, Perek-Białas 2013). Similar results have been found in other countries (Conen 2013; Henkens, van Dalen 2013). However, the role of employers in retirement decisions is still underestimated and requires further research. The pension system that defines exit schemes and the eligible retirement age is the fundamental tool shaping retirement processes; however, employers are the key actors in defining the opportunities for retirement and the opportunities for working longer. In order to better understand individual decisions about leaving the labour market in older age we should consider the role of the employer. As well, the success of public policies aimed at increasing the effective exit age depends to a large extent on the actions and attitudes of employers. Their behaviour results not only from economic calculations and a fully rational assessment of the situation, but also from stereotypes, prejudices, mental models, and knowledge and limitations of the social, political and cultural reality. An expected (by the employer) decrease in job performance and developmental potential, expected increase of costs and shortening remaining career time contributes to the diminishing future value of the ageing worker. It can lead to adverse mechanisms. For employers, low productivity of older workers means potential costs and losses. For employees, a negative attitude and reluctance of employers can adversely affect their professional situation and opportunities in the labour market. This means that regardless of the real potential, productivity and retirement plans of a worker, the employer's opinions have an impact on the work situation and retirement decisions. 


\section{REFERENCES}

Adams, Gary A. 1999. Career-Related Variables and Planned Retirement Age: an Extension of Beehr's Model, "Journal of Vocational Behavior" 55(2): 221-235.

Andrade, Pedro and Ana Maria Sotomayor. 2011. Human Capital Accounting-Measurement Models, "International Journal of Economics and Management Sciences" 1(3): 78-89.

Arrow, Kenneth J. 1998. What has economics to say about racial discrimination?, "Journal of Economic Perspectives" 12(2): 91-100.

Barth, Erling 1997. Firm-specific seniority and wages, "Journal of Labor Economics" 15(3): 495-506.

Becker, Gary S. 1964. Human Capital: A Theoretical and Empirical Analysis, with Special Reference to Education (3rd Ed. 1993), Chicago: The University of Chicago Press.

Beehr, Terry A. 1986. The Process of Retirement: A Review and Recommendations for Future, "Personnel Psychology" 39(1): 31-56.

Beehr, Terry A., Sharon Glazer, Norma L. Nielsonand Suzanne J. Farmer. 2000. Work and Nonwork Predictors of Employees' Retirement Ages, "Journal of Vocational Behavior" 57(2): 206-225.

Ben-Porath, Yoram 1967. The Production of Human Capital and the Life Cycle of Earnings, "The Journal of Political Economy" 75(4): 352-365.

Bidewell, John, Barbara Griffin and Beryl Hesketh. 2006. Timing of retirement: Including a delay discounting perspective in retirement models, "Journal of Vocational Behavior" 68(2): 368-387.

Bishop, John. 1987. The Recognition and Reward of Employee Performance, "Journal of Labor Economics" 5(4): 36-56.

Blau, David M. 1998. Labor Force Dynamics of Older Married Couples, "Journal of Labor Economics" 16(3): 595-629.

Blumberg, Melvin and Charles D. Pringle. 1982. Opportunity Organizational Theory Work, "The Missing Opportunity in Organizational Research: Some Implications for a Theory of Work Performance" 7(4): 560-569.

Booth, Alison L. and Jeff Frank. 1996. Seniority, Earnings and Unions, "Economica" 63(252): 673-686.

Carmichael, Lorne. 1983. Firm-specific human capital and promotion ladders, "The Bell Journal of Economics" 14(1): 251-258.

Clark, Robert, Juanita Kreps and Joseph Spengler. 1978. Economics of Aging: Survey, “Journal of Economic Literature" 16(3): 919-962.

Conen, Wieteke S. 2013. Older workers: the view of Dutch employers in a European perspective, Amsterdam: Amsterdam University Press.

Daveri, Francesco and Mika Maliranta. 2007. Age, seniority and labour costs: lessons from the Finnish IT revolution, "Economic Policy" 22(1): 117-175.

Denzau, Arthur and Douglass North. 1994. Shared Mental Models: Ideologies and Institutions, "Kyklos" 47(1): 3-31.

Dustmann, Christian and Costas Meghir. 2005. Wages, Experience and Seniority, "The Review of Economic Studies" 72(1): 77-108. 
Feldman, Daniel C. 1994. The Decision to Retire Early: A Review and Conceptualization, "The Academy of Management Review" 19(2): 285-311.

Flamholtz, Eric G. 1972a. On the Use of the Economic Concept of Human Capital in Financial Statements: A Comment, "The Accounting Review" 47(1): 148-152.

Flamholtz, Eric G. 1972b. Toward a Theory of Human Resource Value in Formal Organizations, "The Accounting Review" 47(4): 666-678.

Flamholtz, Eric G. 1999. Human Resource Accounting: Advances in Concepts, Methods, and Applications, New York: Springer Science and Business Media.

Flamholtz, Eric G., Maria L. Bullen and Wei Hua. 2002. Human resource accounting: a historical perspective and future implications, "Management Decision" 40(10): 947-954.

Fitz-enz, Jac. 2009. The ROI of human capital: measuring the economic value of employee performance, New York: American Management Association.

García-Pérez, J. Ignacio, Sergi Jiménez-Martín and Alfonso R. Sánchez-Martín. 2013. Retirement incentives, individual heterogeneity and labor transitions of employed and unemployed workers, "Labour Economics" 20: 106-120.

Granovetter, Mark. 1985. Economic action and social structure: the problem of embeddedness, “American Journal of Sociology" 91(3): 481-510.

Greller, Martin M. and Patricia Simpson. 1999. In Search of Late Career: A Review of Contemporary Social Science Research Applicable to the Understanding of Late Career, "Human Resource Management Review" 9(3): 309-347.

Gröjer, Jan-Erik and Ulf Johanson. 1998. Current development in human resource costing and accounting: Reality present, researchers absent?, “Accounting, Auditing \& Accountability Journal" 11(4): 495-505.

Guillemard, Anne-Marie and Martin Rein. 1993. Comparative patterns of retirement: recent trends in developed societies, "Annual Review of Sociology" 19: 469-503.

Hanushek, Eric A. and Nancy L. Maritato (eds). 1996. Assessing Knowledge of Retirement Behavior, Washington: National Academy Press.

Harper, Sarah, Hafiz T.A. Khan, Atulya Saxena and George Leeson. 2006. Attitudes and Practices of Employers towards Ageing Workers: Evidence from a Global Survey on the Future of Retirement, "Ageing Horizons" (5): 31-41.

Harris, Milton \& Bengt Holmstrom. 1982. Theory of Wage Dynamics, "The Review of Economic Studies" 49(3): 315-333.

Hellerstein, Judith K. and David Neumark. 2007. Production Function and Wage Equation Estimation with Heterogeneous Labor Evidence from a New Matched Employer-Employee Data Set, in: Ernst R. Berndt, Charles R. Hulten eds, "Hard-to-Measure Goods and Services: Essays in Honor of Zvi Griliches", Chicago: University of Chicago Press: 31-71.

Henkens, Kène and Hendrik P. van Dalen. 2013. The Employer's Perspective on Retirement, in: Mo Wang (ed.), The Oxford Handbook of Retirement, New York: Oxford University Press, pp. 215-227.

Hinrichs, Karl. 2009. Elephants on the move. Patterns of public pension reform in OECD countries, "European Review" 8(03): 353.

Holzmann, Robert. 2013. Global pension systems and their reform: Worldwide drivers, trends and challenges, "International Social Security Review" 66(2): 1-29. 
Hutchens, Robert. 1987. A test of Lazear's theory of delayed payment contracts, "Journal of Labor Economics" 5(4): 153-170.

Hutchens, Robert. 1989. Seniority, wages and productivity: A turbulent decade, "The Journal of Economic Perspectives" 3(4): 49-64.

Ilmakunnas, Pekka, Mika Maliranta and Jari Vainiomäki. 2004. The roles of employer and employee characteristics for plant productivity, "Journal of Productivity Analysis" 21(3): 249-276.

Ilmarinen, Juhani E. 2001. Aging workers, "Occupational and Environmental Medicine" 58(8): 546-552.

Ilmarinen, Juhani E. and Kaija Tuomi. 1992. Work ability of aging workers, "Scandinavian Journal of Work, Environment \& Health" 18(2): 8-10.

Kotlikoff, Laurence and Jagadeesh Gokhale. 1992. Estimating a firm's age-productivity profile using the present value of workers earnings, "The Quarterly Journal of Economics" 107(4): 1215-1242.

Krzyżowski, Łukasz 2011. Strategie przechodzenia na emeryture w Polsce po 1989 roku. Oczekiwania społeczne i praktyki kulturowe, "Studia Socjologiczne" 2(201): 165-189.

Krzyżowski, Łukasz, Wojciech Kowalik, Katarzyna Suwada and Anna Pawlina. 2014. Młodzi emeryci w Polsce. Między biernościq a aktywnościa, Warszawa: Wydawnictwo Naukowe Scholar.

Lazear, Edward P. and Robert L. Moore. 1984. Incentives, productivity, and labor contracts, “The Quarterly Journal of Economics" 99(2): 275-296.

Lazear, Edward P. 1979. Why Is There Mandatory Retirement?, "The Journal of Political Economy" 87(6): 1261-1284.

Lev, Baruch and Aba Schwartz. 1971. On the Use of the Economic Concept of Human Capital in Financial Statements, "The Accounting Review" 46(1): 103-112.

Lumsdaine, Robin. 1996. Factors Affecting Labor Supply Decisions and Retirement Income, in: Eric A. Hanushek, Nancy L. Maritato (eds), Assessing Knowledge of Retirement Behavior, Washington: National Academy Press, pp. 61-122.

Mathieu, John E., Tonia S. Heffner, Gerald F. Goodwin, Eduardo Salas and Janis A. CannonBowers. 2000. The influence of shared mental models on team process and performance, “The Journal of Applied Psychology" 85(2): 273-83.

McEvoy, Glenn M. and Wayne F. Cascio. 1989. Cumulative evidence of the relationship between employee age and job performance, "Journal of Applied Psychology" 74(1): 11-17.

Medoff, James L. and Katharine G. Abraham. 1980. Experience, performance, and earnings, "Quarterly Journal of Economics" 9(4): 703-736.

Medoff, James L. and Katharine G. Abraham. 1981. Are Those Paid More Really More Productive? The Case of Experience, "Journal of Human Resources" 16(2): 186-216.

Mincer, Jacob A. 1958. Investment in Human Capital and Personal Income Distribution. "The Journal of Political Economy" 66(4): 281-302.

Mincer, Jacob A. 1974. Age and Experience Profiles of Earnings, in: Jacob A. Mincer (ed.), Schooling, Experience, and Earnings, vol. 1, New York: Columbia University Press, pp. 64-82. 
Morse, Wayne J. 1973. A Note on the Relationship Between Human Assets and Human Capital, "The Accounting Review" 48(3): 589-593.

MPiPS. 2008. Dezaktywizacja osób w wieku okołoemerytalnym, Warszawa: Ministerstwo Pracy i Polityki Społecznej.

Neumark, David. 2006. Productivity, Compensation, and Retirement, in: Gordon L. Clark, Alicia H. Munnell and Michael J. Orszag (eds), The Oxford Handbook of Pensions and Retirement Income, Oxford: Oxford University Press, pp. 721-739.

Ng, Thomas W.H. and Daniel C. Feldman. 2008. The relationship of age to ten dimensions of job performance, "The Journal of Applied Psychology" 93(2): 392-423.

OECD. 2012. OECD Pensions Outlook 2012. Paris.

Perek-Białas, Jolanta and Konrad Turek. 2011. Starszy pracownik z punktu widzenia pracodawcy, in: Janusz Mucha, Łukasz Krzyżowski (eds), Ku socjologii starości. Starzenie się w biegu życia jednostki, Kraków: Wydawnictwa AGH, pp. 131-151.

Perek-Białas, Jolanta and Konrad Turek. 2012. Organisation-level policy towards older workers in Poland, "International Journal of Social Welfare" 21(1): 101-116.

Perry, Elissa L. and Lisa M. Finkelstein. 1999. Toward a broader view of age discrimination in employment-related decisions: a joint consideration of organizational factors and cognitive processes, "Human Resource Management Review" 9(1): 21-49.

Phelps, Edmund. 1972. The statistical theory of racism and sexism, "The American Economic Review" 62(4): 659-661.

Phillipson, Chris 2006. The Political Economy of Old Age, in: Malcolm L. Johnson (ed.), Cambridge Handbook of Age and Ageing", Cambridge UK: Cambridge University Press, pp. 502-509.

Polachek, Solomon W. and W. Stanley Siebert. 1993. The Economics of Earnings, New York: Cambridge University Press.

Posthuma, Richard and Michael Campion. 2007. Age Stereotypes in the Workplace: Common Stereotypes, Moderators, and Future Research Directions, "Journal of Management" 35(1): 158-188.

Shultz, Kenneth S., Kelly R. Morton and Joelle R. Weckerle. 1998. The Influence of Push and Pull Factors on Voluntary and Involuntary Early Retirees' Retirement Decision and Adjustment, "Journal of Vocational Behavior" 53(1): 45-57.

Skirbekk, Vegard. 2004. Age and Individual Productivity: A Literature Survey, "Vienna Yearbook of Population Research" 1: 133-154.

Sturman, Michael C. 2003. Searching for the Inverted U-Shaped Relationship Between Time and Performance: Meta-Analyses of the Experience/Performance, Tenure/Performance, and Age/Performance Relationships, "Journal of Management" 29(5): 609-640.

Taylor, Mary A. and Lynn M. Shore. 1995. Predictors of planned retirement age: an application of Beehr's model, "Psychology and Aging" 10(1): 76-83.

Taylor, Philip and Alan Walker. 1998. Employers and older workers: attitudes and employment practices, "Ageing and society" 18(6): 641-658.

Turek, Konrad and Jolanta Perek-Białas. 2013. The role of employers opinions about skills and productivity of older workers: example of Poland, "Employee Relations" 35(6): 648-664. 
Van Dalen, Henrik P., Kène Henkens and Joop Schippers. 2009. Dealing with older workers in Europe: a comparative survey of employers'attitudes and actions, "Journal of European Social Policy" 19(1): 47-60.

Vickerstaff, Sarah, Jennefer Cox and Linda Keen. 2003. Employers and the Management of Retirement, "Social Policy and Administration" 37(3): 271-287.

Zukin, Sharon and Paul DiMaggio. 1990. Introduction, in: Sharon Zukin, Paul DiMaggio (eds), Structures of Capital: The Social Organization of the Economy. Cambridge, MA: Cambridge University Press, pp. 1-36.

\section{DECYZJA O PRZEJŚCIU NA EMERYTURĘ JAKO EFEKT RELACJI POMIĘDZY PRACODAWCĄ I PRACOWNIKIEM}

Pracodawcy są kluczowymi aktorami definiującymi warunki przejścia na emeryturę, jak również warunki kontynuowania pracy, jednak ich rola nadal nie jest w pełni rozpoznana i ujęta w ramy teoretyczne. Aby lepiej zrozumieć indywidualne decyzje emerytalne oraz projektować politykę względem starzenia się ludności, musimy uwzględnić zachowania i postawy pracodawców.

Artykuł omawia proces przejścia na emeryturę rozpatrywany z perspektywy organizacyjnej, prezentując teoretyczne ujęcie roli pracodawców oraz środowiska pracy. Dyskutowane są klasyczne podejścia ekonomiczne, między innymi model odroczonej zapłaty, oraz w nawiązaniu do socjologii gospodarki i nauk o zarządzaniu zaprezentowana jest perspektywa pracodawców w relacji ze starszym pracownikiem. Głównym celem artykułu jest charakterystyka procesu przejścia na emeryturę jako wyniku relacji pomiędzy pracodawcą i pracownikiem.

Słowa kluczowe: emerytura, starzejący się pracownicy, relacje pomiędzy pracodawcą i pracownikiem, zakorzenienie 